\title{
Apresentação da tradução
}

\section{"LÊNIN NA INGLATERRA": MARIO TRONTI E O OPERAÍSMO ITALIANO}

\author{
Thiago Silva Augusto da Fonseca ${ }^{1}$
}

Resumo: O artigo "Lênin na Inglaterra", de Mario Tronti, publicado originalmente na primeira edição de Classe operaia, em 1964, e traduzido para o português por Homero Santiago, pode ser considerado um documento consolidador do pensamento operaísta, vertente marxista italiana nas décadas de 1960 e 1970. Pretendemos aqui apresentar o momento vivido na Itália em que o texto aparece, além de uma breve trajetória de seu autor, militante do hoje extinto Partido Comunista Italiano e atual senador daquele país. Palavras-chave: Mario Tronti - Itália - Lênin - PCI - operaísmo - hipótese operaísta.

Michael Hardt, em Laboratório Itália - introdução que redigiu para a coletânea de artigos de militantes italianos que publicou, com Paolo Virno, nos EUA -, afirma que a Itália vinha, na última década do século XX, "americanizando-se". Certamente referia-se a um processo de transformação da estrutura produtiva, por um lado, e estatal, de outro, que tornava Itália e EUA similares. O lado positivo desse fenômeno era que a "bota" então tornava-se menos estranha, menos "anômala" do que havia sido nas décadas de 60 e 70 e, consequentemente, que sua história recente se tornava cada vez mais acessível - Hardt tinha em mente um público conterrâneo seu. O interesse que ele atribuía à Itália não era pequeno:

$\mathrm{Na}$ época de Marx, o pensamento revolucionário parecia girar sobre três eixos: filosofia alemã, economia inglesa e política francesa. Em nossa época os eixos mudaram, de forma que, se continuarmos dentro do mesmo quadro euro-americano, o pensar revolucionário, pode-se dizer, recorre à filosofia francesa, à economia estadunidense e à política italiana. ${ }^{2}$

A política italiana a que Hardt se referia não era apenas aquela institucional, a do Partido Comunista Italiano (PCI), a da Democracia Cristã (DC), mas também, e principalmente, a da esquerda extraparlamentar, daquilo que veio a ser chamado de operaísmo

\footnotetext{
${ }^{1}$ Mestre em Filosofia pela FFLCH-USP. E-mail: thiagofonseca@hotmail.com.

${ }^{2}$ HARDT, "Introduction: Laboratory Italy", p. 1.
} 
e que, posteriormente, transformou-se em autonomismo. Trata-se, portanto, de uma política operária, política de conflito entre trabalho e capital. Se é verdade que a luta de classes move a história, o acirramento dos confrontos na Itália é exemplar para a compreensão das rápidas transformações pelas quais o mundo passou na segunda metade do século XX. Não se tratou, em caso algum, de "história de marginais, excentricidade periférica ou fantasia sectária de algum gueto subterrâneo"', segundo os próprios militantes em carta escrita no cárcere após a derrota dos movimentos. A vitória - parcial - do capital foi alcançada através do terrorismo de Estado, cujo golpe final se deu em 1979, com a prisão de diversos membros de organizações da esquerda extraparlamentar. ${ }^{4}$

No entanto, estamos colocando o carro na frente dos bois. É preciso voltar e dar conteúdo a esse nome, operaísmo. Para dizer em poucas palavras, trata-se de um conjunto de trabalhos teóricos e práticas militantes que se desenvolveu na esquerda italiana a partir do fim da década de 1950, conjunto heterogêneo e por vezes conflituoso cuja unidade se dá por um interesse comum, o da análise da composição da classe operária feita a partir do desenvolvimento industrial do país - o chamado "Milagre Econômico". Não apenas desenvolver teorias ou pensamento, os operaístas tinham por objetivo, ao fazer o "estudo real de uma fábrica real', analisar a relação entre a composição técnica e a composição política da classe trabalhadora no estágio contemporâneo do capitalismo e, com isso, decidir a respeito da organização do movimento e suas lutas. ${ }^{5}$

Nessa perspectiva, as próprias formas partido e sindicato foram sendo postas em questão. No caso do partido, isso se deu, num primeiro momento, em função da decepção com a submissão do PCI às decisões soviéticas após a Segunda Guerra Mundial; mais tarde, pelo fato de o partido comunista ter se coligado com a DC, ou seja, com os interesses do capital e não com os dos trabalhadores. No caso dos sindicatos, o problema vem desde os impactos gerados pelo Plano Marshall e pela integração da Itália no Mercado Comum Europeu. Graças a esses fatores, o norte do país se industrializou rapidamente, enriqueceuse, atraindo força de trabalho do sul, que permaneceu pobre e agrícola. Ao longo da década de 50, para se ter uma ideia, a Fiat - que possuía em Turim a maior fábrica do mundo - se orgulhava de ter vencido o comunismo: seus empregados, satisfeitos com os salários e não alinhados à $\mathrm{CGIL}^{6}$, não entravam em conflito com o patronato, como se houvesse uma harmonia de interesses. Mas a leva de trabalhadores vindos do sul para ocupar os postos nos

\footnotetext{
${ }^{3}$ NEGRI, VIRNO et al., "Do you remember revolution?”, p. 225.

${ }^{4}$ Entre eles Antonio Negri, acusado de ser o mandante do sequestro e assassinato do primeiro-ministro Aldo Moro no ano anterior.

${ }^{5}$ Cf. WRIGHT, Storming heaven: class composition and struggle in Italian Autonomist Marxism, introdução.

${ }^{6}$ CGIL: Confederação Geral Italiana do Trabalho, comunista, uma das três maiores entidades sindicais da Itália, ao lado da CISL (Confederação Italiana de Sindicatos dos Trabalhadores, católica) e da UIL (União Italiana dos Trabalhadores, socialista).
} 
novos pátios vai alterar esse quadro, e é isso que as pesquisas feitas pelos operaístas buscam apreender.

Em 1960, começam a ser publicados os Quaderni rossi, capitaneados por Raniero Panzieri, que vinha do Partido Socialista Italiano (PSI), tendo como colaboradores, entre outros, Mario Tronti, do PCI, Romano Alquati, sociólogo, e Antonio Negri, professor de Filosofia do Direito em Pádua. O ponto de partida da publicação é justamente a percepção de mudança nas condições de trabalho sem que, em contrapartida, houvesse adequação nas atividades sindicais correspondentes. Já começa a se esboçar aquilo que viria a ser propriamente o operaísmo, poucos anos depois, com a revista Classe operaia. Em primeiro lugar, com a afirmação de Panzieri de que não há desenvolvimento do capital fora das relações de classes; mas principalmente com a atenção dada pelos autores da revista ao surgimento de uma nova classe operária, caracterizada por novas necessidades e novos comportamentos, paralelo à recomposição do trabalho fabril que estava em curso, ou seja, à implantação de novas máquinas que não exigiam do operário qualquer qualificação, substituindo os antigos trabalhadores por jovens.

Em Turim, por exemplo, é realizada por Romano Alquati uma enquete operária entre os trabalhadores da Fiat. A "co-pesquisa" mostra que os processos ditos "objetivos" de reorganização do trabalho não fazem nenhum sentido que não seja político: o interesse do capital é fazer com que os trabalhadores aceitem a estrutura e a hierarquia de poder da empresa como fatos naturais, quando na realidade as novas máquinas são instrumentos não só de produção como também de controle sobre a classe, na medida em que dispensam os antigos operários profissionais e contratam jovens para operá-las, num trabalho que não requeria mais qualificação. ${ }^{7}$ Além disso, o estudo revela que essa reorganização não elimina o antagonismo, pois os trabalhadores já começavam a se mobilizar - mas o faziam espontaneamente, independentemente dos sindicatos e, por vezes, de modo hostil a estes.

Essas "novas pessoas", essa "nova classe", eram justamente os trabalhadores oriundos do sul, que não tinham sido bem recebidos no norte e, portanto, não tinham vida social a não ser no local de trabalho; trabalhadores desqualificados, dominados pelas máquinas, que realizavam atividades repetitivas e sem sentido e que, por isso, não sentiam qualquer orgulho pelo trabalho, mas antes um desprezo pela fábrica; trabalhadores que promoviam greves repentinas ("gatto selvaggio"), sem aviso prévio aos patrões, sem autorização da justiça trabalhista e sem participação dos sindicatos, pois não se sentiam representados

\footnotetext{
${ }^{7}$ Cf. ALQUATI, "Documenti sulla lotta di classe ala FIAT". Na mesma publicação, Panzieri afirmava que o uso capitalista das máquinas não era "uma simples distorção ou desvio de um desenvolvimento 'objetivo', em si mesmo racional", uma vez que o desenvolvimento tecnológico é determinado por esse uso interessado. "O processo de industrialização", prossegue Panzieri, "gradualmente se apoderando de estágios mais avançados de progresso tecnológico, coincide com o incessante aumento da autoridade do capitalista". Cf. PANZIERI, "Sull'uso capitalistico delle macchine nel neocapitalismo", p. 55.
} 
por estes - tudo aquilo que viria a caracterizar o chamado "operário massa". Segundo o historiador Steve Wright, "o relato de Alquati dá início aos discursos de composição de classe - entendida como as várias formas de comportamento que emergem quando formas particulares de força-trabalho são inseridas em processos específicos de produção - o que logo viria a ser sinônimo do próprio operaísmo". ${ }^{8}$ Pensar a especificidade da classe operária foi, assim, o grande feito dos Quaderni rossi contra a presunção de se tomar a classe como algo dado, imutável - uma classe "mitologizada".

No entanto ocorre já em 1962 uma ruptura entre aqueles que estavam envolvidos com a publicação. Durante as negociações para a renovação da convenção coletiva dos metalúrgicos, os sindicatos convocam greve geral em maio, junho e julho. Em 07 de julho, pela manhã, espalha-se a notícia de que a UIL e a SIDA (sindicato patronal) haviam firmado a convenção separadamente dos metalúrgicos, o que gera enfrentamentos na Fiat em Turim. Muito trabalhadores jovens, que não se sentem representados pelos sindicatos, vão à Piazza Statuto, onde ficava a sede da UIL, e invadem o prédio. Os líderes do PCI e da CGIL pedem em vão que voltem a suas casas. O enfrentamento dura três dias e deixa marcas nas relações entre os trabalhadores e seus representantes que repercutirão profundamente na prática e na teoria do movimento operário italiano nos anos seguintes.

Na ocasião, Panzieri se posicionou contrariamente à invasão e às manifestações dessa "nova classe trabalhadora". Os demais colaboradores, favoráveis à mobilização, deixam os Quaderni rossi para publicar, a partir de janeiro de 1964, a revista Classe operaia, que visava continuar a pesquisa teórica da sua publicação antecessora e fortalecer a ação política nas fábricas. A nova publicação, dirigida por Tronti, segue o caminho dos Quaderni rossi em busca da compreensão da nova classe operária e das novas formas de organização. O primeiro número abre-se com "Lênin na Inglaterra", texto de Mario Tronti que pode ser considerado como o texto inaugural do operaísmo, uma vez que elabora aquilo que veio a ser conhecido como hipótese operaísta.

Muitos anos depois, Antonio Negri, após a prisão, o exílio na França, o retorno à Itália e novo encarceramento, e tendo já escrito dois livros com Michael Hardt, tecerá grandes elogios a Tronti. ${ }^{9}$ Segundo aquele, há, na Itália do século XX, apenas dois filósofos depois de Gramsci: Luísa Murari, que apontou para a exploração da mulher pelo homem, e Tronti, que ensinou sobre a exploração do homem pelo homem. Tronti foi o "Lênin italiano".

\footnotetext{
${ }^{8}$ Sobre os Quaderni rossi e a enquete operária realizada por Alquati, cf. WRIGHT, Storming heaven..., especialmente o capítulo 2 .

${ }^{9}$ Em La differenza italiana, publicado em 2003, quando Negri e Hardt já haviam publicado juntos $O$ trabalho de Dioniso e Império, além da revista Futur Antérieur.
} 
Leninismo, no entanto, é uma expressão equívoca. O Lênin de Negri não é o mesmo de Tronti. Havia, ainda, outros. De acordo com o historiador Mimmo Sersante, na Itália das décadas de 50, 60 e 70, "todo o debate sobre o partido e sobre a relação classe-partido girava em torno da figura do grande revolucionário russo, e era normal que assim o fosse”. PCI e PSI discutiam os textos de Lênin e formavam seus quadros a partir deles ${ }^{10}$, ainda que se tratasse, do ponto de vista de Negri, de adesão "ortodoxa", "gramscismo reformista". Além disso, outros grupos marxistas faziam da figura do líder ou do grupo dirigente um fetiche, transformando o leninismo em marxismo-leninismo stalinista. ${ }^{11}$ Vejamos, pois, qual o leninismo de Tronti.

Romano, desde jovem Tronti esteve próximo a grupos antifascistas que fazem parte da história da cidade e, quando ingressou na Universidade de Roma, ligou-se à célula comunista, que realizava um grupo de leitura "não-oficial" das obras de Marx. A heterodoxia se dava pela aproximação com Galvano Della Volpe e sua abordagem que ia na contracorrente do "historicismo" da geração anterior, atribuído tanto a Benedetto Croce quanto a Antonio Gramsci, ou melhor, ao Gramsci tal como foi apreendido por Palmiro Togliatti, longevo líder do PCI. ${ }^{12} \mathrm{O}$ interesse do grupo em afastar-se da leitura oficial do partido é em parte explicada pela publicação do Relatório Khrushchev, em 1956: se até então todos no grupo de Tronti eram stalinistas - no sentido de aderir totalmente à experiência soviética -, a depuração dos crimes de Estado da URSS os leva a outros caminhos que os do partido, que ainda estava sob a sombra do Soviete Supremo. É nesses novos rumos que se dá o encontro com Panzieri, que então já havia rompido com o PSI. Com ele, Tronti e seus amigos passam a frequentar Turim, constituindo o grupo romano dos Quaderni rossi. ${ }^{13}$

O afastamento relativo à oficialidade do partido, no entanto, não implicará, no caso de Tronti, em rompimento. Quando, ao longo da década de 60, se intensificarem as mobilizações operárias "anárquicas", ele as vivenciará de dentro do PCI, o que o coloca numa posição sui generis relativamente a muitos outros militantes e teóricos do operaísmo, a ponto mesmo de afirmar que nunca teve uma formação propriamente operaísta, mas tão somente comunista. Seu único e breve momento de desligamento do partido se deu durante o período de publicação de Classe operaia. O operaísmo consistiu, assim, apenas uma experiência na sua vida, um experimento político-intelectual concentrado ${ }^{14}$; um entre outros, como o da

\footnotetext{
10 SERSANTE, Il ritmo delle lotte. La pratica teorica di Antonio Negri (1958-1979), p. 67.

${ }^{11}$ Cf. o prefácio à reedição de 2004 de NEGRI, Trentatre lezioni su Lenin.

12 Tal historicismo, mesmo na linha Gramsci-Togliatti, encontraria uma continuidade entre Hegel e Marx, não uma ruptura. Para Della Volpe, era necessário abandonar esse historicismo com suas hipóstases idealistas em prol de hipóteses materialistas. Cf. GENTILI, Italian Theory. Dall'operaismo alla biopolitica, pp. 27 e segs.

13 Sobre a juventude de Tronti, cf. BORIO, POZZI e ROGGERO (org.), Gli operaisti. Autobiografie di cattivi maestri, pp. 289 e segs.

14 "Um encontro entre um novo marxismo e uma nova classe operária". Idem, p. 292.
} 
autonomia do político, pelo qual foi muito criticado pelos demais operaístas quando do seu retorno ao partido.

Especificamente no que diz respeito ao operaísmo, que tipo de experimento tinha Tronti em mente? O de levar adiante alguns apontamentos levantados pelos Quaderni rossi, onde havia descoberto não somente o Lênin da organização, mas o da análise do capitalismo na Rússia, o "Lênin marxiano". "A grande tese leninista", afirma Tronti, "era a de que era necessário tomar, por parte operária, as rédeas da revolução burguesa, para levá-la às últimas consequências". Tronti vai se perguntar se com isso não havia uma recaída no historicismo - "quanto mais se desenvolve o capitalismo mais se desenvolvem suas contradições internas". No entanto, tal consequência não se verifica empiricamente, pois o capital mantém controle sobre o trabalho, ainda que se empenhe em remover a centralidade operária. Não que não exista a classe; não se trata de um problema sociológico, mas sim político. Tornouse portanto necessário passar de volta da análise à organização. ${ }^{15}$

Mas os Quaderni rossi eram um instrumento mais analítico que propositivo, uma revista de difícil leitura e que saía apenas uma vez ao ano. Dessas dificuldades nasce a ideia de um jornal operário, o Classe operaia, cujo subtítulo era mensile politico degli operai in lotta [mensário político dos operários em luta], dedicado à narrativa operária das lutas, o que foi alcançado - "talvez com uma ambição excessiva porque não queria limitar-se à situação italiana mas estender o olhar às lutas operárias na Europa". Mais que relatar as lutas, organizálas era o maior objetivo de Tronti. Por isso Lênin - não um Lênin qualquer, mas um "Lênin na Inglaterra".

Conforme o leitor e a leitora poderão verificar na tradução que se segue, Tronti afirmará, com razão, que o nome de Lênin está definitivamente ligado à organização. ${ }^{16} \mathrm{E}$ nada mais justo, portanto, que sua proposição da criação de um jornal para o desenvolvimento da tarefa. Afinal, o célebre texto Que faz̧er?, de Lênin, se inicia e se encerra com a defesa da necessidade da publicação de um jornal operário e revolucionário para toda a Rússia, um jornal que fosse um organizador coletivo. Evidentemente, o "trabalho de papel" de um jornal não se opõe ao trabalho político real na base, é antes um instrumento deste, como bem sabia Lênin. Ainda assim, o trabalho de papel tem uma enorme importância, para cuja elucidação Lênin apresenta uma metáfora. Numa obra grandiosa, muitos pedreiros vão colocando pedras e cimento para construir, por exemplo, um prédio. Não basta que eles colem as pedras de maneira dispersa: é preciso um prumo para a obra, um trabalho de papel, teórico, para coordenar o trabalho comum. Esse é o sentido do jornal e, no fundo, da organização: dar o prumo do movimento em toda a Rússia. Não se faz isso por um simples

${ }^{15}$ Idem, p. 297.

16 "A própria ideia de organização ocupa no leninismo um lugar essencial: organização do instrumento revolucionário, organização da própria revolução, organização da sociedade surgida com a revolução”. Marcel Liebman apud BORON, "Estudo introdutório: Atualidade de Que fazer??”, p. 13. 
gosto pelo comando; trata-se antes de respeito pela retidão do prumo, e não por um ou outro sujeito oficial que dê ordens. Afirma ainda Lênin que todos parecem concordar com a necessidade de reunião e de organização - por exemplo, dos diversos círculos socialdemocratas de uma cidade, de uma região, criando organismos comuns, de trabalho comum, que possam compartilhar os recursos humanos e materiais para uma atividade de maior alcance. Pois bem, prossegue, somente sobre a base de um jornal comum para toda a Rússia esses vínculos se estabeleceriam e se efetivariam. Com ele, os círculos locais terão os contornos gerais de uma obra comum que todos estarão realizando, e por isso saberão encaminhar suas atividades com confiança. ${ }^{17}$

É bem verdade que aquilo que lá Lênin propôs diz respeito a um momento muito específico da luta operária na Rússia. Segundo o comentador Lars T. Lih, Que fazer? é apenas um documento histórico, embora um documento fascinante, não porque inventa qualquer coisa, mas antes porque "recapitula as aspirações e a experiência prática de pessoas que tentaram aplicar um conjunto particular de suposições numa situação particular". ${ }^{18}$ No entanto, se por um lado pode nos ser óbvia a posição histórica das proposições de Lênin, por outro isso não quer dizer que com elas não possamos aprender nada. O que, então, quer dizer "Lênin na Inglaterra"? O mesmo Lênin transplantado, reterritorializado? Outro Lênin? Tronti conclui seu artigo com uma explicação:

A estratégia leninista, com um golpe magistral, levou Marx a Petersburgo: só o ponto de vista operário podia ser capaz de semelhante audácia revolucionária. Experimentemos fazer o caminho inverso, com o mesmo espírito científico de aventurosa descoberta política. Lênin na Inglaterra é a pesquisa de uma nova prática marxista do partido operário: o tema da luta e da organização no mais alto nível de desenvolvimento político da classe operária.

Não o mesmo Lênin, portanto, mas o mesmo "espírito científico", a "pesquisa de uma nova prática marxista do partido operário". Não mais em Petersburgo, mas na Inglaterra - lugar que representa o "mais alto nível de desenvolvimento político da classe operária". A inversão do caminho é apenas uma dentre aquelas que o texto oferece. A mais importante e

\footnotetext{
${ }^{17}$ Cf. LÊNIN, Que fazer?, em especial "Por onde começar" e o capítulo V.

${ }^{18} \mathrm{Cf}$. LIH, Lenin rediscovered: What is to be done? in context, pp. 554-555. Além disso, o próprio Lênin afirmava já em 1907 que "o principal erro dos que hoje polemizam com Que fazer? reside em dissociá-lo por completo de determinadas condições históricas, de determinada fase do desenvolvimento do nosso partido que já foi superada há muito tempo". E em seguida: "Que faz̧er? é um resumo da tática do Iskra [Faísca], da política de organização do Iskera em 1901 e 1902. É apenas isso, um resumo, nem mais nem menos”. LÊEIN, Que faz̧er?, pp. 82-83.
} 
mais caracteristicamente operaísta é a inversão do ponto de vista, a assunção radical da "audácia revolucionária". Aqui nasce propriamente a referida hipótese operaísta, cujo escopo é o de renovar as perspectivas de luta da classe operária não a partir das leis de desenvolvimento do capital, mas das leis de desenvolvimento da própria classe trabalhadora. Assim, vemos Tronti afirmar:

Nós também vimos primeiro o desenvolvimento capitalista, depois as lutas operárias. É um erro. Cumpre inverter o problema, mudar o sinal, recomeçar do princípio: e o princípio é a luta de classe operária. Ao nível do capital socialmente desenvolvido, o desenvolvimento capitalista é subordinado às lutas operárias, vem depois delas e a elas deve fazer corresponder o mecanismo político da própria produção.

Trata-se de resgatar a subjetividade operária, não como mera "proposição retórica" ou como discurso motivacional, mas como uma tese cientifica. "O ponto de partida do novo discurso", prossegue o autor,

nos diz que, no nível nacional e internacional, a atual particular situação política da classe operária guia e impõe um certo tipo de desenvolvimento do capital. Trata-se de recompreender à luz desse princípio a inteira rede mundial das relações sociais.

É importante que se diga que, apesar do caráter científico da proposição, não se deve esperar dela resultados "objetivos". O que Tronti buscava era uma ciência "rude e ameaçadora", um ponto de vista social não-objetivo e sem pretensão à objetividade, afirma Wright. ${ }^{19}$ Não à toa, a hipótese operaísta, como assunção do ponto de vista do trabalhador, como inversão de perspectiva, foi tida como a "revolução copernicana" dos operários. ${ }^{20}$

Como se pode ver, trata-se de uma posição forte, prenhe de consequências. Wright aponta para a acusação de "hegelianismo operário" que Tronti sofreu a partir da redação de "Lênin na Inglaterra", acusação feita por ninguém menos que seu companheiro dos Quaderni rossi, Panzieri, que afirmou tratar-se de

um resumo fascinante de toda uma série de erros que nesse momento pode acometer a esquerda operária. É fascinante porque é muito hegeliano, em

19 WRIGHT, Storming heaven..., pp. 82 e segs.

${ }^{20}$ Cf. ALTAMIRA, Os marxismos do novo século, p. 148. 
sentido original, como novo modo de reviver uma filosofia da história... uma filosofia da história da classe operária. ${ }^{21}$

Talvez seja uma acusação exagerada ${ }^{22}$; talvez não, se pensarmos na posteridade de Tronti, que não só não pôde desmantelar o Estado a partir de dentro (ao insistir no partido), como também veio a se tornar, em 2004, presidente do Centro para a Reforma do Estado, fundação instituída pelo PCI em 1972 como centro de estudos. Especulações à parte, não deixa de ser curioso notar que também Lênin foi alvo de tal tipo de censura. Plekhanov, companheiro de redação do Iskra que inicialmente havia defendido Que fazer? dos ataques que, segundo sua próprias palavras, não faziam mais do que apanhar frases isoladas do texto e o definiam como uma filosofia da história, acabou por romper com Lênin e fazer justamente o mesmo, atribuindo a ele posições idealistas, como a de um suposto paralelismo da "relação espontaneidade-consciência ao tema da relação entre o ser e a consciência". ${ }^{23}$

$* * *$

Não cabe a esta apresentação fornecer a leitura correta, seja ela apologética ou não, de "Lênin na Inglaterra". Esse é um exercício que cabe ao leitor e à leitora. Podemos apenas apontar aos rumos tomados por seu autor a partir daquela publicação.

Olhando em retrospecto, já no século XXI, Tronti afirma que sua pretensão com a publicação de Classe operaia era a de "formar, no contato direto com a luta operária, um tipo de grupo dirigente a ser reinserido, depois da experiência, na grande política" - ou seja, reinserido no PCI, para de dentro dele levar as mobilizações a uma posição revolucionária. E acrescenta:

Eu, então dentro do espírito do operaísmo (e isso está documentado em muitos textos), nunca fui um espontaneísta, ou, para dizê-lo em outras palavras, nunca fui um luxemburguista, como era Panzieri, que acreditava na forma da auto-organização; eu (e aqui reaparece minha formação comunista) fui leninista, sempre pensei e continuo pensando que sem uma direção política nenhum movimento social vinga, e disto não tive desmentidos. ${ }^{24}$

\footnotetext{
21 Apud WRIGHT, Storming heaven..., p. 61.

$22 \mathrm{O}$ que seria menos o caso se pensássemos na apropriação dessa inversão de perspectiva feita por Hardt e Negri em Império, por exemplo, onde os autores ampliam o alcance da hipótese operaísta para fazer dela uma operação de compreensão de toda a modernidade a partir do Renascimento - e a adéquam à formulação foucaultiana de que "onde há poder há antes resistência".

23 GETARRANA, "Stalin, Lênin e o marxismo-leninismo”, p. 227.

${ }^{24}$ BORIO, POZZI e ROGGERO (org.), Gli operaisti. Autobiografie di cattivi maestri, pp. 289 e segs., pp. 300 e 295.
} 
Eis portanto o leninismo de Tronti. E se vê aí o alcance da contribuição que Classe operaia poderia oferecer aos operários que caminhavam rumo à autonomia. Já em 1966, apenas dois anos após o primeiro número da revista, Tronti decide encerrar a publicação, com receio de que ela não seria capaz de formar mais do que um grupo "viciado", autorreferencial, que repetisse indefinidamente sua própria experiência como grupo minoritário, apartado, incapaz de intervenção no rumo das lutas. Portanto, um grupo desorganizado. O caminho de Tronti, ao voltar ao PCI, foi também o de autonomia - no seu caso, no entanto, não autonomia operária, mas a autonomia do político ${ }^{25}$, o que o colocou em rota de colisão com a esquerda extraparlamentar, em especial no curso da década de 1970, quando o partido firma o famigerado "Compromisso histórico" com a Democracia Cristã o partido da ordem, por assim dizer -, que veio a reprimir duramente as lutas operárias. Segundo Wright, dentro de pouco tempo “o 'experimento político de novo tipo' de Tronti reverteu a uma tática de tipo verdadeiramente velho" - a reafirmação da centralidade do PCI na política revolucionária. ${ }^{26}$

Não queremos com isso afirmar que Tronti revela sua face autoritária, antioperária ou algo do tipo, mas sim apontar aos limites que encontrou ao firmar seus compromissos, seja com a Democracia Cristã, seja com a forma-Estado. No entanto, cumpre ressaltar que as mobilizações do longo 68 italiano (que durou de 1969 até 1979 e trouxe ao clássico projeto comunista da revolução "novos" fenômenos sociais, tais como demandas feministas, estudantis e de redução do preço de moradia e das tarifas de transporte e de eletricidade) enfrentaram resistência justamente do partido que se supunha representá-las. Em 1983, os militantes encarcerados, na carta a que nos referimos no início desta apresentação, assim descreviam a situação dos anos anteriores:

A extrema polarização do confronto de classes e a relativa pobreza das mediações políticas institucionais (com um sistema de bem-estar demasiadamente centralizado) criou uma situação na qual conflitos por maiores salários e mais liberdade vincularam-se à meta leninista de 'esmagar a máquina estatal'. ${ }^{27}$

\footnotetext{
25 Segundo Alberto Toscano, a formulação da autonomia do político tratava de "um modo de alcançar a hegemonia da classe operária sobre a racionalização e o planejamento econômicos". Cf. TOSCANO, "Chronicles of insurrection", p. 122.

26 WRIGHT, Storming heaven..., p. 68. Nesse sentido, podemos pensar que a insistência de Tronti na formapartido seja um leninismo ao pé da letra, se lembrarmos que Lênin, em polêmica contra o jornal Rabotchéie Dielo [Causa Operária], ao insistir que o partido deveria adaptar suas táticas imediatamente às mudanças nas situações enfrentadas, defendia que "para mudar de tática é necessário antes ter uma tática, e sem uma organização forte (...) não se pode nem sequer falar em um plano de atividade sistemática” (cf. LÊNIN, Que fazer?, p. 97).

${ }^{27}$ NEGRI, VIRNO et al., "Do you remember revolution?”, p. 226.
} 
A opção de Tronti pelo entrismo, isto é, pela defesa dos interesses operários por vias estatais, cobrou seu preço. O Estado italiano não foi esmagado - foi reformado. Ou pior. Ao invés de uma possível revolução, a reação veio na forma da contrarrevolução, definida por Paolo Virno como "literalmente revolução em reverso. Em outras palavras, uma inovação impetuosa de modos de produção, formas de vida e relações sociais que, no entanto, consolidam e novamente põem em movimento o mando capitalista". ${ }^{28}$ A contrarrevolução que teve início nos anos 1970 na Itália prosseguia até meados dos anos 1990, momento em que Virno publica seu texto. Trata-se da "afirmação integral do modo de produção pósfordista", pelo qual os operários, de certa forma, lutaram, mas em sua versão pervertida, perversa. O neoliberalismo italiano que então se instalou foi, de certa forma, resposta às lutas. E isso não é outra coisa que a hipótese operária atualizada.

Também não queremos afirmar que o PCI foi um agente ativo nessa vitória parcial - do capital. O Compromisso histórico, segundo Virno, se desfez em 1979, e “o poder de iniciativa política retornou inteiramente para as mãos do grande negócio e dos partidos de centro". Já em 1980, Enrico Berlinguer, então secretário geral do partido, esteve na linha de frente de uma greve na Fiat contra um plano de reestruturação que levou a 30 mil demissões. ${ }^{29}$

Mas talvez já fosse tarde para conter a contrarrevolução. Entre 84 e 89, verifica-se um grande crescimento econômico - isto é, de lucros - na Itália. Despontam empresas do mercado financeiro, como a Fininvest, de Silvio Berlusconi, do mercado de moda, como a Benetton, e também as indústrias química e automobilística. O custo desse crescimento econômico foi pago no campo social - segundo Virno, aquilo que Marx chamava de exército de reserva acabou se tornando a própria classe trabalhadora, na medida em que o "novo profissional", o "trabalhador autônomo" passou a ser marcado por desemprego, precariedade e insegurança, a título de "flexibilização".

Em 1990, o PCI se dissolve e é formado o PDS, Partido Democrático da Esquerda, pelo qual Tronti foi eleito senador em 1992. Já era sinal de uma transformação do sistema político italiano, com um enfraquecimento do sistema representativo. Em 1993, após um referendo, as eleições deixam de ser proporcionais para ser majoritárias. Paralelamente, com a condenação judicial de uma grande parte corrupta dos partidos tradicionais, o cenário ia se transformando. A DC tornou-se em 1994 Partido Popular. Partidos de centro sumiram do mapa. Forma-se uma nova direita, cujo discurso e cuja prática são "menos" conservadores que inovadores: uma direita neoliberal. Seus dois principais sujeitos organizadores foram a Lega Nord, separatista,e a Forza Italia, de Berlusconi, não por acaso proprietário de meios de

28 VIRNO, “Do you remember counterrevolution?", p. 241.

${ }^{29}$ Cf. idem, pp. 247 e segs. 
comunicação de larga escala num momento em que o trabalho comunicativo, em sua forma pervertida, tornava-se central para a produção capitalista de valor. A gestão empresarial vai se tornar a única forma de governo possível, de um Estado que não mais esconde de que lado está. ${ }^{30}$

O vínculo entre Estado e capital não é novo, o conhecemos há mais de 150 anos, com a publicação de $O 18$ de Brumário de Luís Bonaparte. A ênfase de Tronti será, no entanto, outra. O Estado neoliberal não é o Estado liberal. Enquanto este remonta a uma tradição europeia do século XIX, aquele vem de outro lugar e outro tempo: os EUA do século XX. Aqui reencontramos aquela afirmação de Michael Hardt sobre a "americanização" da Itália na década de 1990. E com a percepção desse "novo Estado de coisas", o ponto sobre o qual Tronti passou a insistir, em textos mais recentes, é que o movimento operário foi derrotado não pelo capitalismo, mas pela democracia.

A questão é delicada, e por isso é importante precisar o que Tronti tem em mente com essa afirmação. Segundo ele, a Europa não foi liberada pelos estadunidenses na Segunda Guerra - ela foi americanizada, democratizada. Como dissemos, a tradição europeia era liberal, pautada no indivíduo; na tradição trazida dos EUA, é a massa que ganha espaço: o Estado social é Estado da massa, massa no singular, Estado da formação de blocos identitários. Esse "universalismo democrático", prossegue Tronti, "abole as diferenças de classes", substituindo-as por "blocos de consenso" quase simétricos em termos de quantidade de votos: $52 \%$ de votos para um partido x 48\% para outro; democratas $\mathrm{x}$ republicanos; burgueses progressistas $\mathrm{x}$ burgueses reacionários. ${ }^{31} \mathrm{Em}$ linhas muito gerais, sua crítica é à democracia política, ou à democracia como única esfera possível da política, em que a conflituosidade se reduz ao sistema de sufrágio como único caminho possível, o da "escolha" da melhor gestão para o Estado. Nesse cenário a indústria de comunicação e de espetáculo, com seus "formadores de opinião", encontram terreno fértil. A democracia que Tronti vem descrevendo corresponde à massificação. E é quantitativa, como a economia: quanto se tem, quanto se produz, quanto se consome, quanto se vota. Não é o indivíduo a unidade da democracia, mas a massa, ou indivíduo massificado; a democracia é orgânica ao capitalismo. Essa é, segundo ele, a "democracia real", tal como se manifesta (do mesmo

\footnotetext{
30 “O naufrágio completo do Estado só se revelou de fato no momento em que passou a ser capitaneado por um homem que tomou o teatro da política clássica e tem todo seu programa orientado justamente em torno de rejeitá-la e substituí-la por uma gestão puramente empresarial. Nesse ponto, o Estado se assume abertamente como partido. Com Berlusconi, não se trata de um indivíduo singular que toma o poder, mas sim uma forma de vida: a do pequeno empreendedor limitado, arrivista e filofascista do norte da Itália". TIQQUN, Isto não é um programa, pp. 110-111.

31 Quanto a burgueses progressistas e reacionários, isso se dá em função do conceito que Tronti oferece para compreender o trabalho dito imaterial e a sociedade que o acompanha: não o operário social, mas o burguês de massa. Sobre esse ponto e os seguintes, cf. TRONTI, L'enigma democratico e Per la critica della democrazia politica, disponíveis na internet.
} 
modo que se fala em "socialismo real" para descrever o que se passou, por exemplo, na União Soviética) e que deveríamos pôr em xeque.

Não somente delicada, a questão é polêmica, na medida em que Tronti vai defender, numa posição que chamará de ademocrática, um "elitismo" da classe operária, uma "aristocracia" dos trabalhadores. Seria esse o retorno do leninismo da juventude de Tronti? A vanguarda e o revolucionário profissional como elite, como aristocracia? E se democracia e socialismo são nomes que não mais servem àquilo pelo que se luta, como nomeá-lo? A ver. São questões em aberto que já escapam do âmbito desta apresentação.

\section{“LENIN IN ENGLAND”: MARIO TRONTI AND THE ITALIAN WORKERISM}

Abstract: Mario Tronti's article "Lenin in England", published in the first edition of Classe operaia, in 1964, and now translated to Portuguese by Homero Santiago, may be taken as the defining document on workerism, an Italian Marxist line of thought and action in the 1960's and 1970's. Our goal in this paper is to present what was happening in Italy at the time that the text came out, as well as a brief account on the author's steps, militant at the now extinct Italian Communist Party and currently senator at that country. Keywords: Mario Tronti - Italy - Lenin - ICP - workerism - workerist hypothesis.

\section{REFERÊNCIAS BIBLIOGRÁFICAS}

ALQUATI, Romano. "Documenti sulla lotta di classe alla FIAT”, Quaderni rossi, Roma, 1961, no 1, pp. 198-215.

ALTAMIRA, Cesar. Os marxismos do novo século. Rio de Janeiro: Civilização Brasileira, 2008.

BORIO, Guido, POZZI, Francesca e ROGGERO, Gigi (org.). Gli operaisti. Autobiografie di cattivi maestri. Roma: DeriveApprodi, 2005.

BORON, Atílio. "Estudo introdutório: Atualidade de Que fazer?". Em LÊNIN, Vladimir Ilich. Que fazer?: a organização como sujeito político, pp. 9-79.

GENTILI, Dario. Italian Theory. Dall'operaismo alla biopolitica. Bolonha: Il Mulino, 2012.

GETARRANA, Valentino. "Stalin, Lênin e o marxismo-leninismo", em HOBSBAWN, Eric J. (org.). História do marxismo. O marxismo na época da terceira internacional: problemas da cultura e da ideologia (vol. 9). Rio de Janeiro: Paz e Terra, 1987, pp. 221-255.

HARDT, Michael. "Introduction: Laboratory Italy". Em HARDT e VIRNO (org.), Radical thought in Italy, pp. 1-10. 
HARDT, Michael e VIRNO, Paolo (org.). Radical thought in Italy. Minneapolis: University of Minnesota Press, 1996.

LÊNIN, Vladimir Ilich. Que fazer?: A organização como sujeito politico. São Paulo: Martins Fontes, 2006.

LIH, Lars T. Lenin rediscovered: What is to be done? in context. Chicago: Haymarket Books, 2008.

NEGRI, Antonio. Trentatre lezioni su Lenin. Roma: Manifestolibri, 2004.

NEGRI, Antonio, VIRNO, Paolo et al. "Do you remember revolution?". Em HARDT, Michael e VIRNO, Paolo (org.). Radical thought in Italy, pp. 225-238.

PANZIERI, Raniero. "Sull'uso capitalistico delle macchine nel neocapitalismo", em Quaderni rossi, Roma, 1961, n 1, pp. 53-72.

SERSANTE, Mimmo. Il ritmo delle lotte. La pratica teorica di Antonio Negri (1958-1979). Verona: Ombre Corte, 2012.

TIQQUN, Isto não é um programa. Dazibao: São Paulo, 2014.

TOSCANO, Alberto. "Chronicles of insurrection”, em CHIESA, Lorenzo e TOSCANO, Alberto (org.). Italian difference. Between nibilism and biopolitics. Melbourne: re.press, 2009, pp. 109-128.

TRONTI, Mario. L'enigma democratico. 2007. Disponível na internet em http://www.sinistrainrete.info/teoria/63-lenigma-democratico.html - Per la critica della democrazia politica. 2008. Disponível na internet em http://www.sinistrainrete.info/teoria/321-httpwininfoautorgimmaginiheadgif-per-lacritica-della-democrazia-politica.html

VIRNO, Paolo. “Do you remember counterrevolution?”. Em HARDT, Michael, e VIRNO, Paolo. Radical thought in Italy, pp. 241-259.

WRIGHT, Steve. Storming heaven: class composition and struggle in Italian Autonomist Marxism. Londres: Pluto Press, 2002. 